\title{
P. Rossing \\ Prediction, progression and prevention of diabetic nephropathy. The Minkowski Lecture 2005
}

Received: 9 September 2005 / Accepted: 17 October 2005 / Published online: 9 December 2005

(C) Springer-Verlag 2005

\begin{abstract}
Diabetic nephropathy is a major problem for patients and health care systems. The costs of treatment remain high. To confront the ongoing challenge, we need to identify individuals at high risk for initiation and progression of this devastating complication. Risk factors include genetic markers; constitutional factors such as low birthweight; haemodynamic factors, including activation of the RAS system and hypertension; metabolic factors such as glycaemia; and additional factors such as urinary AER and smoking. Modifiable risk factors should be treated aggressively. Potential new markers of risk include indices of increased inflammation, changes in coagulation, endothelial dysfunction, growth factors and cytokines. Application of such markers may in time improve risk assessment and allow new treatment targets to be identified. Interventions that aim to achieve strict glycaemic control and blockade of the renin-angiotensin system have been shown to be effective in clinical trials and are feasible in clinical practice. The 'natural history' of diabetic nephropathy can be transformed if these strategies of intensive screening and care are applied, leading both to a lower incidence of diabetic nephropathy and to an improved outcome, with survival exceeding 20 years from onset of overt proteinuria.
\end{abstract}

Keywords ACE inhibition - Diabetic nephropathy · Dual blockade $\cdot$ Epidemiology · Microalbuminuria · Progression of renal disease - Progression promoters . Type 1 diabetes

Abbreviations RAS: renin-angiotensin system

\section{Introduction}

Diabetic nephropathy has become the leading cause of endstage renal disease in the United States, Europe and Japan. Furthermore, the number of affected patients in India and China and other parts of the developing world is growing rapidly, creating a worldwide burden both for patients and health care systems. The syndrome is characterised by persistent albuminuria ( $>300 \mathrm{mg} / 24 \mathrm{~h}$ or $200 \mu \mathrm{g} / \mathrm{min}$ ), early elevation of arterial blood pressure, a relentless decline in renal function, and increased cardiovascular morbidity and mortality. Previous studies found a cumulative risk of 25 $40 \%$ after a diabetes duration of at least 25 years in type 1 and type 2 diabetes [1-3]. More recent epidemiological data suggest that it is possible to improve the outcome and reduce the number of patients developing overt diabetic nephropathy and other diabetic microvascular complications with improved diabetes care, although these positive results may so far be limited to dedicated centres [4]. In order to reduce the number of patients who develop diabetic nephropathy, it is important to understand the mechanisms underlying progression. This should make it possible to identify additional initiators and factors promoting progression, potentially leading to targeted therapy. It will also enable patients at high risk of initiation or of accelerated progression of diabetic nephropathy to be identified, enabling clinical care to be focused upon them. This review will focus upon identification of patients at risk for development and progression of diabetic nephropathy, consideration of modifiable progression promoters, and possible ways of improving treatment.

\section{Risk factors for development of diabetic nephropathy}

Progression from normoalbuminuria to microalbuminuria defines the initiation of diabetic nephropathy, and the transition from microalbuminuria to overt diabetic nephropathy resulting in deterioration of renal function and end-stage renal disease constitutes its progression. The presence of microalbuminuria is associated with increased 
cardiovascular morbidity and mortality, and regular screening is recommended in guidelines for diabetes care [5]. In an attempt to find risk factors and markers for progression from normoalbuminuria to microalbuminuria, we followed a cohort of 537 normoalbuminuric type 1 diabetic patients for 10 years. Identified in a cross-sectional study in 1984 [6], these patients had a median duration of diabetes of 20 years at baseline, and $25 \%$ developed microalbuminuria during follow-up. In a more recent study [7], we followed a separate cohort of 277 type 1 diabetic patients from onset of diabetes (i.e. an inception cohort) for 18 years, during which time $29 \%$ developed microalbuminuria.

\section{Genetic risk factors}

The observation of familial clustering of diabetic nephropathy [8-10], and of racial variation in the development of diabetic renal complications [11], suggest that genetic factors are involved in the development of diabetic nephropathy. This is currently considered a complex genetic trait, requiring a combination of alleles of several genes in addition to environmental factors. Several candidate genes have been studied, including diabetes susceptibility genes and genes involved in glucose metabolism and regulation of blood pressure, in addition to the growth factor genes reviewed by Tarnow [12]. Owing to small sample sizes and differences in design and the populations studied, the results have been conflicting. Genes involved in the renin-angiotensin system (RAS) have attracted particular interest, and the insertion/ deletion polymorphism in the gene for ACE, related to circulating levels of ACE, was shown in a meta-analysis to have a modest effect on the risk for development of diabetic nephropathy in patients of European extraction [13]. In accordance with the concept of a complex genetic trait, it has been suggested that much larger studies ( $>1,000$ patients) will be needed before analysis of combinations of genetic traits will become possible.

\section{Constitutional factors}

It has been suggested that intrauterine growth retardation will lead to a reduction in nephron number, and hence to an inborn deficiency in renal functional reserve capacity [14] (Fig. 1). In our follow-up study of the inception cohort we demonstrated that slightly elevated urinary albumin excretion at onset of diabetes already predicted the development of microalbuminuria [7]. It is possible that this slight increase in urinary albumin excretion is a marker of abnormal glomerular haemodynamic and permselective conditions predisposing to diabetic glomerulopathy as a result of a reduction in renal functional reserve capacity. Birthweight is directly associated with adult height, and could therefore also explain why short stature (low birthweight) in this and previous studies was related to initiation of microalbuminuria [7] and the presence of diabetic nephropathy [15], as well as to development of microalbuminuria in non-diabetic men [16]. In type 1 diabetic women

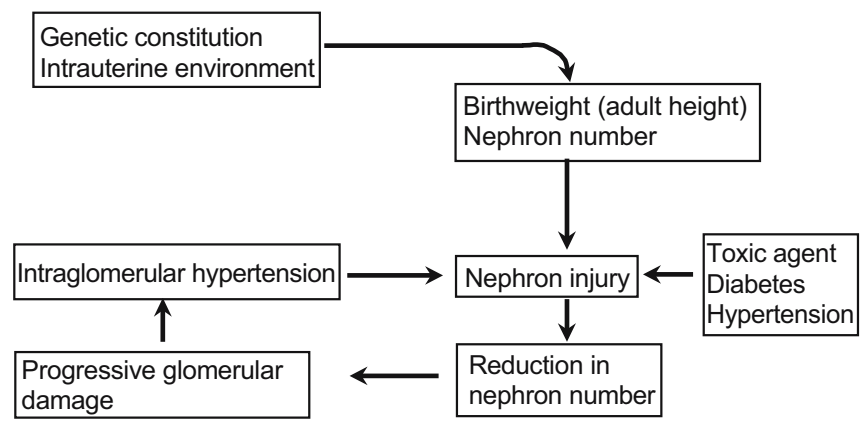

Fig. 1 The relationship between low birthweight, reduced functional renal reserve capacity (nephron number) and increased susceptibility to renal disease [115]

with intrauterine growth retardation (birthweight below the 10th percentile) we demonstrated an increased risk for development of diabetic nephropathy [17]. This supports the hypothesis that factors operating in utero or early life and genetic predisposition are both associated with initiation of diabetic nephropathy, a suggestion that has also been made for other renal diseases [18].

\section{Systemic hypertension}

Our study of the inception cohort suggests that at onset of diabetes a small increase in systemic blood pressure, within the normal range, is already important for the initiation of diabetic nephropathy [7]. This is in accordance with several other studies, but not all were able find such an association $[6,19-22]$, possibly due to differences in study design and study population or to differences in methods of blood pressure measurement. Since the changes in blood pressure are small and may be more pronounced at night, 24-h ambulatory blood pressure measurements may be more precise [23]. A study of 75 type 1 diabetic patients followed for a mean of 5 years with repeated measurements of ambulatory blood pressure further suggested that a change in diurnal variation in blood pressure with loss of nocturnal dipping could be observed prior to the development of microalbuminuria, although non-dipping at baseline was not predictive for progression [23].

\section{Oral contraceptives-RAS activation}

The importance of the activated RAS in the development of diabetic renal disease is reflected by the predictive effect of elevated prorenin levels $[24,25]$. Since oral contraceptives also activate the RAS, we evaluated the impact of their use on the RAS in diabetic subjects, and found an elevated activity in those on oral contraceptives as compared with non-users. This was assessed by the renal haemodynamic effects of acute RAS blockade with the ACE inhibitor captopril in subjects on a high-sodium diet [26]. The clinical impact was evaluated in a longitudinal follow-up study in which $18 \%$ (six of 33 ) of oral contraceptive users compared with $2 \%$ (two of 81 ) of non-users of oral 
contraceptives developed overt diabetic nephropathy ( $p=0.008$ after adjustment for known risk factors) (Fig. 2) [26]. Large prospective studies are required to investigate this relationship further, but a population-based study also reported an association between use of oral contraceptives or hormonal replacement therapy and the presence of microalbuminuria [27].

\section{Hyperglycaemia}

The relationship between hyperglycaemia and the development of microvascular complications was described by Pirart [28] and has since been demonstrated in many observational studies $[6,7,19-21,29,30]$. Furthermore, intensive therapy aimed at improving glycaemic control reduced the risk for development of diabetic nephropathy and retinopathy (primary prevention) in the smaller randomised studies combined in a meta-analysis by Wang [31], and these findings were confirmed and extended in the Diabetes Control and Complications Trial [32]. It has been suggested that glucose induces vascular damage through four pathways: (1) increased polyol pathway flux; (2) increased advanced glycation end-product formation; (3) activation of protein kinase $C$; and (4) increased hexosamine pathway flux [33]. Overproduction of superoxides by the mitochondria is considered a common link between these pathways [34, 35]. This suggests new treatment options for the future, but blocking these pathways has not so far been feasible or effective in man.

\section{Smoking}

We observed an increased risk for the development of microalbuminuria in smokers in our 10-year follow-up study [29]. Several other observational studies have found the same [30,36], although others failed to demonstrate this relationship [21, 37]. An observational study of 943

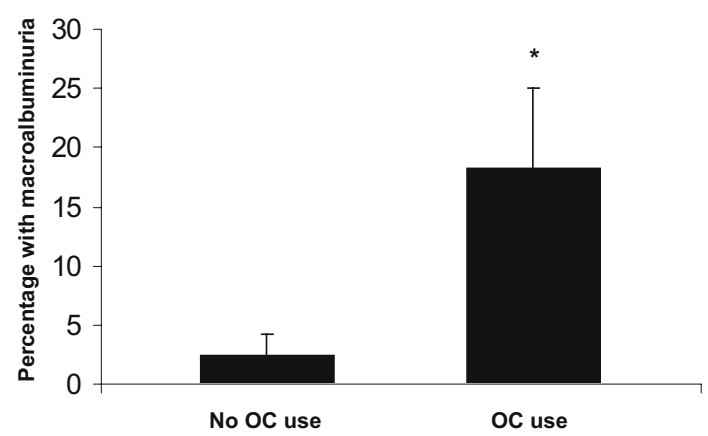

Fig. 2 Oral contraceptive $(O C)$ use and the development of macroalbuminuria in an inception cohort of 114 type 1 diabetic women (81 OC users) followed for a mean period of 20 years. ${ }^{*} p=0.003$, and in a Cox model adjusted for known risk factors relative risk $=8.9(95 \%$ CI $1.79-44.36, p=0.008)$. Copyright $(C 2005$ American Diabetes Association. From Diabetes Care (2005) 28:1988-1994. Reprinted with permission from The American Diabetes Association [26] type 1 diabetic patients followed for 4 years found that smoking modified the effect of hyperglycaemia, magnifying the influence of poor glycaemic control [30]. Smoking is thus an obvious modifiable risk factor, although intervention studies have not been performed to confirm this. The mechanisms are poorly understood, but an abrupt rise in systolic blood pressure and heart rate has been observed during the course of heavy smoking, although there was no effect on microalbuminuria or GFR [38]. Smoking has also been proposed as a modifiable progression promoter [39]; however, when we followed 301 type 1 diabetic patients with overt diabetic nephropathy for at least 3 years with a precise measure of GFR we found no impact of smoking on the rate of decline in GFR [40].

Risk assessment for development of microalbuminuria

Over 10 years of follow-up, $25 \%$ of initially normoalbuminuric patients developed microalbuminuria. This enabled us to create a simple risk assessment scheme (Fig. 3), demonstrating that the risk of progression from normoalbuminuria to microalbuminuria and macroalbuminuria within 10 years was $70 \%$ if the patient had a combination of four risk factors, namely, retinopathy, urinary AER $>10 \mathrm{mg} / 24 \mathrm{~h}$, $\mathrm{HbA}_{1} \mathrm{c}>8.6 \%$ and smoking, as against only $10 \%$ risk of progression if none of these risk factors were present [6]. Similar data emerged for type 2 diabetic patients (P. Rossing, unpublished data). This type of risk assessment is convenient to use in the clinical situation and can be used to identify highrisk individuals for intervention trials.

\section{Does microalbuminuria predict progression to overt nephropathy?}

The presence of microalbuminuria was originally found to be predictive of overt diabetic nephropathy in $80 \%$ of type 1 diabetic patients untreated with antihypertensive agents,

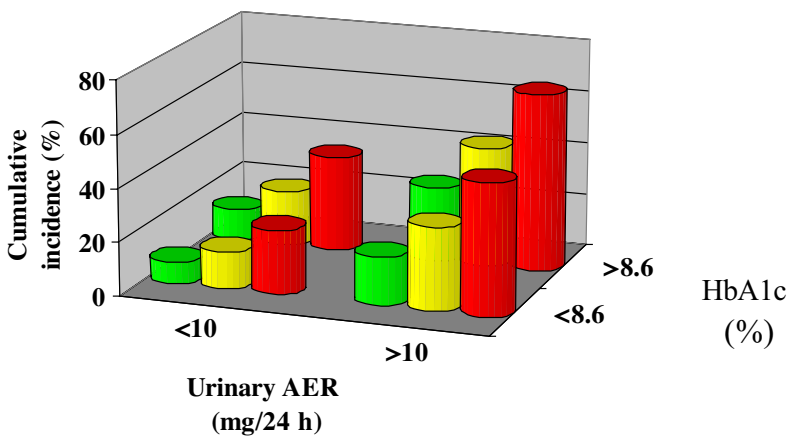

Fig. 3 Individual risk of progression to microalbuminuria during 10 -year follow-up in type 1 diabetic patients with normoalbuminuria. Based on the presence or absence of $\mathrm{HbA}_{1} \mathrm{c}>8.6 \%$, urinary AER $>10 \mathrm{mg} / 24 \mathrm{~h}$, and the number of additional risk markers (smoking and/or diabetic retinopathy). Green 0 additional risk factors, yellow 1, red two. Copyright(C 2002 American Diabetes Association. From Diabetes Care (2002) 25:859-864. Reprinted with permission from The American Diabetes Association [6] 
after 6-14 years of follow-up [41-43]. More recent studies found overt nephropathy in only $30-45 \%$ of microalbuminuric patients after 10 years $[7,44]$. This decrease may be due to earlier and more aggressive treatment of blood pressure, and ACE inhibitors in particular have been shown to reduce progression to overt nephropathy in normotensive type 1 diabetic patients with microalbuminuria [45]. It has further been suggested that as many as $58 \%$ of patients with microalbuminuria may revert to normoalbuminuria [46], bringing the value of microalbuminuria as a predictor of overt nephropathy into question [47]. Other studies with longer follow-up periods found spontaneous regression to normoalbuminuria in only $13-15 \%$ of patients; additional treatment-induced regression was seen in a similar number [7, 44], suggesting that microalbuminuria remains an important risk factor.

\section{Microalbuminuria in diabetes of long duration}

In the initial studies, in which up to $80 \%$ of patients progressed to overt nephropathy, the duration of diabetes was short. In an observational study of longer term type 1 diabetes (duration $>15$ years) the rate of progression over 10 years of follow-up was only $28 \%$ [48], and a small study from the UK found that $32 \%$ of patients with microalbuminuria and a type 1 diabetes duration of $>30$ years progressed to overt nephropathy [49]; these studies excluded patients with a short duration of diabetes. In a prospective observational study of 181 microalbuminuric type 1 diabetic patients, we found that the rate of progression to overt nephropathy was $45 \%$ in those with a diabetes duration of $<15$ years, as compared with a rate of $26 \%$ in patients with a duration $\geq 15$ years [44]. In microalbuminuric type 1 diabetes patients with $>40$ years of diabetes, the incidence of overt nephropathy was $4 \%$ per year.

Raised arterial blood pressure was not associated with risk of progression from microalbuminuria to overt nephropathy in observational studies of type 1 diabetic patients [44, 50-52] although more sensitive methods, such as 24-h blood pressure measurements, should possibly have been used [53]. Changes in blood pressure were only apparent close to the development of overt nephropathy or in relation to metabolic control [54]. Despite this, treatment with antihypertensive medication, ACE inhibitors in particular, has been the most successful means of avoiding progression from microalbuminuria to overt nephropathy (secondary prevention). In a meta-analysis of all randomised trials of at least 1 year's duration in microalbuminuric type 1 diabetic patients, ACE inhibitors reduced progression to overt nephropathy by $62 \%$, and increased regression to normoalbuminuria three-fold compared with placebo [45]. Similar findings came from microalbuminuric type 2 patients treated with an angiotensin II receptor blocker [55]. The effect of ACE inhibition on urinary albumin excretion in microalbuminuric type 1 diabetic patients is long lasting, and GFR was preserved in an 8-year randomised study [56]. What is more, this treatment strategy can be implemented effectively in everyday clinical practice [57].
The importance of glycaemic control for progression to nephropathy has been demonstrated in several studies [44, $48,50,51,58]$, but has been hard to demonstrate in randomised controlled trials with intensive metabolic control $[52,59]$. This might be due to inadequate sample sizes, insufficient separation of mean values for 'intensive' and 'conventional' glycaemic control, or insufficient followup time. In type 1 diabetic patients, pancreas transplantation resulting in normoglycaemia can reverse glomerulopathy in patients with normoalbuminuria $(n=3)$ or microalbuminuria $(n=4)$, but more than 5 years of normoglycaemia are required for this to occur [60].

Improved prediction with cardiovascular risk markers

Additional tests will be needed to improve upon the accuracy of existing risk estimates for development of diabetic nephropathy. Variables that have been investigated include hyperlipidaemia [50], features of the insulin resistance syndrome $[22,50,61,62]$, and a family history of cardiovascular disease $[63,64]$. Cardiovascular risk assessment involves much the same risk factors and markers as renal risk assessment, and there has recently been much interest in biochemical markers or factors associated with putative pathophysiological mechanisms for cardiovascular disease, such as endothelial dysfunction, dysregulation of coagulation and fibrinolysis, complement activation and inflammation [65]. Inflammatory activity is increased in type 1 diabetes [66], and a recent cross-sectional study found an independent association between markers of inflammation (C-reactive protein, IL-6 and TNF- $\alpha$ in a combined index) and the presence of microvascular complications [67]. It has been suggested that microalbuminuria is only associated with progression to overt nephropathy in the presence of endothelial dysfunction [68]. Inflammation and complement activation via the mannose-binding lectin pathway may also play a role in the pathogenesis of diabetic microvascular complications, and a prospective study found that increasing levels of mannose-binding lectin early in the course of type 1 diabetes were significantly and independently associated with the later development of persistent microalbuminuria or macroalbuminuria [69]. Cytokines such as TGF- $\beta$, a prosclerotic cytokine considered to be the major mediator of collagen formation in the kidney, and connective tissue growth factor (another pro-sclerotic cytokine) are other possible markers, but large and prospective studies are lacking. Vascular endothelial growth factor, a cytokine that induces angiogenesis and increases vascular permeability, was elevated in plasma early in the course of diabetic nephropathy, as compared with normoalbuminuric controls, but only in men [70]. The predictive value of these biomarkers and their response to intervention is not yet clear, one problem being that plasma or urinary concentrations of these markers may not reflect local concentrations in the kidney or other organs. These potential markers are, however, of great interest as possible new targets for drug action. 
Structural markers

It has been suggested that structural parameters can be used as outcome predictors, and 5-year follow-up of normoalbuminuric type 1 diabetic patients showed that glomerular basement membrane width was increased at baseline in patients developing microalbuminuria over the study period [71]. It has been argued that morphological changes are sometimes present before functional changes such as microalbuminuria, thereby potentially allowing earlier identification of high-risk individuals [47], but there are few prospective data. It has also been suggested that molecular biology techniques could be applied to renal biopsies. For example, tissue levels of RNA encoding molecules known to be involved in the pathogenesis of renal disorders, determined in routine clinical kidney biopsies, predicted loss of renal function in more advanced stages of nephropathy [72]. The requirement for renal biopsy limits the usefulness of such approaches.

\section{Prediction of progression and treatment efficacy in overt diabetic nephropathy}

When a patient develops overt diabetic nephropathy with persistent macroalbuminuria and elevated arterial blood pressure, kidney function starts to decline. In the microalbuminuric stage, hyperfiltration is often present, and the GFR is usually high or normal at the onset of nephropathy. Before the introduction of antihypertensive therapy, the rate of decline in GFR was $10-20 \mathrm{ml} / \mathrm{min}$ per year [73-76]. Today, antihypertensive medication, particularly blockade of the RAS, has reduced the mean rate of decline in GFR to $2.0-10 \mathrm{ml} / \mathrm{min}$ per year in randomised controlled trials [77-80]. There is, however, still large inter-individual variation in the rate of decline, ranging from stable kidney function to a rapid decline leading to renal replacement therapy or death within a few years. Factors accounting for this large variation in the loss of kidney function have been termed progression promoters, and some possible progression promoters $[81,82]$ are depicted in Fig. 4.

A recent review of putative genetic progression promoters [83] found that the focus has, for the most part, been on genes involved in the RAS, although these genes, even in combination, make only a small contribution

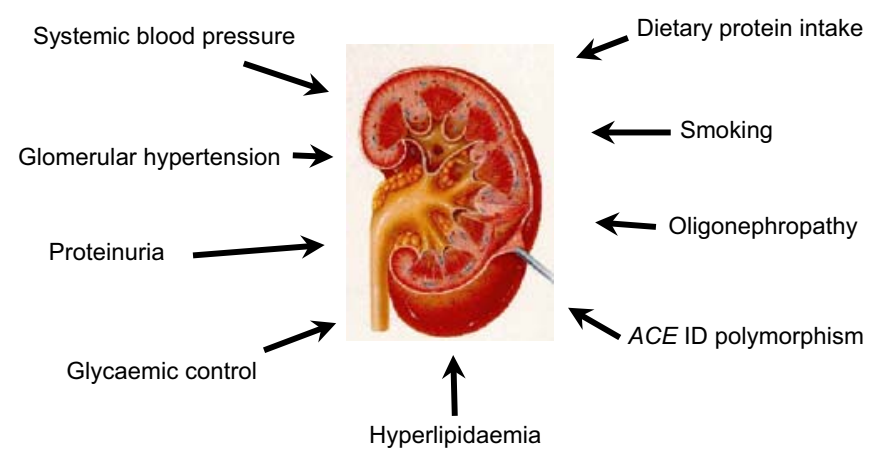

Fig. 4 Putative promoters for progression of diabetic nephropathy to the loss of kidney function [84]. They may, however, contribute to the choice of treatment. In type 1 diabetic patients with overt nephropathy, the rate of decline in renal function during treatment with an ACE inhibitor was accelerated in patients homozygous for the deletion allele D of the insertion/deletion polymorphism as compared with patients homozygous for the insertion allele I or the heterozygous patients [85], whereas the decline in renal function was similar in these patients when treated with an angiotensin II receptor blocker [86]. This implies that the optimal means of blocking the RAS depends upon the genotype. It is also possible that genetic factors related to pharmacodynamic aspects of medication could influence the therapeutic effect [87].

Hypertension and proteinuria are established and modifiable progression promoters [76, 88], and intervention targeting these factors has been the most successful renoprotective treatment in diabetic nephropathy. The primary endpoint in clinical trials of diabetic nephropathy has been the rate of decline in renal function, development of endstage renal disease or death, whereas a reduction in urinary albumin excretion has been considered a surrogate endpoint, a predictor of a beneficial outcome, and a reduction in albuminuria shortly after onset of antihypertensive therapy is the best predictor of long-term preservation of renal function $[89,90]$. Instead of relying solely upon the urinary AER, we may in future be able to study treatment-induced changes in the pattern of the large number of polypeptides excreted in the urine using proteomics with high-throughput mass spectrometry of urine. In a study of type 2 diabetic patients with diabetic nephropathy treated with angiotensin II receptor blockade in a cross-over study, it was possible to identify treatment-induced changes in several excreted polypeptides, inducing partial normalisation of the initial polypeptide pattern that typifies overt diabetic nephropathy [91]

Optimising the intervention in the renin-angiotensinaldosterone system

Despite the success of ACE inhibitors in treating diabetic nephropathy, not all patients obtain satisfactory control of blood pressure, albuminuria and decline in renal function. Studies have therefore tried to optimise the blockade of the renin-angiotensin-aldosterone system by: (1) increasing the doses of medication beyond the doses used to treat hypertension; (2) combining ACE inhibition and angiotensin II receptor blockade (dual blockade); or (3) inhibition of aldosterone.

The doses used have been based on studies of hypertension, and dose-response curves have not been constructed for ACE inhibitors in diabetic nephropathy. The optimal dosing for renoprotection might differ from the doses used in hypertension, although the optimal doses for each were similar in a short-term study of type 1 diabetic patients with nephropathy treated with the angiotensin II receptor blocker losartan [92]. In contrast, a study of the angiotensin II receptor blocker candesartan revealed a different optimal dose for blood pressure response ( $8 \mathrm{mg} /$ day) and renal effects $(16 \mathrm{mg} /$ day $)$ in 
type 2 diabetic patients with nephropathy [93]. Another study showed that, in microalbuminuric type 2 diabetic patients, ultra-high doses of the angiotensin II receptor blocker irbesartan $(900 \mathrm{mg} /$ day $)$ offered an additional antiproteinuric effect of $15 \%$ compared with the usual high dose of $300 \mathrm{mg} /$ day $(p=0.02)$ [94].

As ACE inhibitors and angiotensin II receptor blockers act on different sites in the RAS, combination of the two agents (dual blockade) has been tested. ACE inhibitors have the advantage of increasing bradykinin, but may be bypassed by non-ACE conversion of angiotensin I to angiotensin II [95]. Angiotensin II receptor blockers cannot be bypassed, but incomplete blockade of the angiotensin II receptor type 1 or effects on other angiotensin II receptors are of importance in animal models [96]. The first study to use dual blockade in diabetes was the Candesartan and Lisinopril Microalbuminuria (CALM) study. This included 199 hypertensive microalbuminuric type 2 diabetic patients and found that the combination of lisinopril and candesartan was more effective than either agent alone in reducing blood pressure [97]. In a study of type 1 diabetic patients with overt nephropathy and albuminuria $>1,000 \mathrm{mg} / 24 \mathrm{~h}$ despite antihypertensive therapy including ACE inhibition, addition of the angiotensin II receptor blocker irbesartan reduced albuminuria by $37 \%$ [98]. Similar results were found in type 2 diabetic patients with overt nephropathy [99]. It has been argued that increasing the dose of a single agent might be equally effective [100], but in a study of type 1 diabetic patients with overt nephropathy, addition of the angiotensin II receptor blocker irbesartan to the maximum recommended dose of ACE inhibition produced a $25 \%$ further reduction in albuminuria and a further significant reduction in blood pressure [101]. Since all these studies have been of rather short duration (up to 1 year), longer term trials are needed to establish the role of dual blockade of the RAS in diabetic nephropathy. As regards patients with non-diabetic nephropathy, the Combination Therapy of Angiotensin-II Receptor Blocker and Angiotensin-Converting Enzyme Inhibitor in Non-diabetic Renal Disease (COOPERATE) study, which included 263 patients followed for a median of 3 years, found that only $11 \%$ of patients on dual blockade (trandolapril and losartan) progressed to the clinical endpoint (doubling of serum creatinine or end-stage renal disease), in contrast to $23 \%$ receiving either agent as monotherapy $(p=0.02)$ [102].

There has recently been an additional focus on aldosterone as a mediator of renal and cardiovascular disease via effects on fibrosis, necrosis and inflammation [103]. Clinical trials with blockade of the renin-angiotensin-aldosterone system with ACE inhibitors or angiotensin II receptor blockers demonstrated that aldosterone levels increase in some patients after an initial reduction (the aldosterone escape phenomenon) $[104,105]$. It was further demonstrated that aldosterone levels that rose during treatment were associated with a significantly faster rate of decline in GFR over long-term follow-up [105]. Blocking the effect of aldosterone with spironolactone ( $25 \mathrm{mg} /$ day) in 13 type 2 diabetic patients with aldosterone escape during treatment with an ACE inhibitor induced a significant reduction in albuminuria [104]. This has been confirmed in controlled studies of type 1 and type 2 diabetic patients with diabetic nephropathy $[106,107]$.

\section{Prognosis}

Diabetic patients with microalbuminuria have an increased morbidity and mortality [108-111]. This may be due to progression to overt diabetic nephropathy, or related to an increased risk of the microalbuminuric stage per se. Since urinary albumin excretion has been measured only at baseline in most follow-up studies, this issue could not initially be resolved. We were, however, able to demonstrate in a 10year follow-up study of microalbuminuric type 1 diabetic patients, which included regular measurements of urinary AER, that increased mortality was related to progression to overt nephropathy, and not to the presence of microalbuminuria per se [108]. This implies that the prognosis of microalbuminuric type 1 diabetic patients can be improved provided progression to overt nephropathy can be avoided.

Early studies describing the prognosis of overt diabetic nephropathy observed a median survival of 5-7 years after the onset of persistent proteinuria $[1,112]$. End-stage renal failure was the primary cause of death in $66 \%$ of patients. When deaths attributed only to end-stage renal disease were considered, the median survival time was 10 years [2]. All this was before patients were offered antihypertensive therapy. Long-term antihypertensive therapy was evaluated prospectively in 45 type 1 diabetic patients who developed overt diabetic nephropathy between 1974 and 1978. Ten years after onset of diabetic nephropathy the cumulative death rate was $18 \%$, and the median survival was more than 16 years [113]. We went on to examine whether antihypertensive therapy also improved survival in an unselected cohort of 263 patients with diabetic nephropathy followed for up to 20 years, and observed a median survival of 13.9 years; only $35 \%$ of patients died because of end-stage renal failure (serum creatinine $>500 \mu \mathrm{mol} / \mathrm{l}$ ) [108]. Fortunately, survival continues to improve, and we recently showed a median survival rate of 21 years after onset of diabetic nephropathy [114] (Fig. 5).

In conclusion, a number of potentially modifiable risk factors, including poor glycaemic control, raised blood pressure, increased urinary albumin excretion and smok-

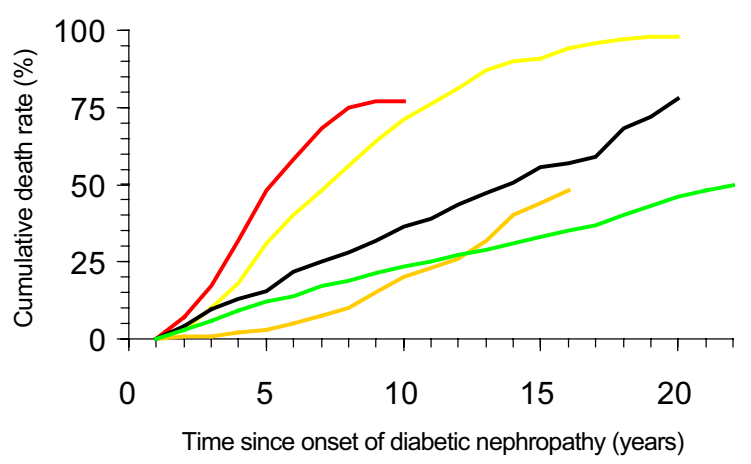

Fig. 5 Cumulative death rate from onset of diabetic nephropathy in type 1 diabetic patients during the natural history of diabetic nephropathy (red line, $n=45$, Knowles [112]; yellow line, $n=360$ Andersen et al. [1]) compared with patients who had effective antihypertensive treatment (orange line, $n=45$, Parving et al. [113]; black line, $n=263$, Rossing et al. [108]; green line, $n=199$, Astrup et al. [114]). From [114] with permission from Blackwell Publishing 
ing, predict the initiation and/or progression of diabetic nephropathy. Microalbuminuria carries a high risk for development of overt diabetic nephropathy. New biomarkers may in future permit more precise risk assessment, but at present it is essential to screen for known risk factors. Interventions aimed at strict glycaemic control, to avoid initiation of diabetic nephropathy, and blockade of the RAS, to avoid its progression, are of demonstrated value in clinical trials and are feasible in clinical practice.

\section{References}

1. Andersen AR, Christiansen JS, Andersen JK, Kreiner S, Deckert T (1983) Diabetic nephropathy in Type 1 (insulindependent) diabetes: an epidemiological study. Diabetologia 25:496-501

2. Krolewski AS, Warram JH, Christlieb AR, Busick EJ, Kahn CR (1985) The changing natural history of nephropathy in Type 1 diabetes. Am J Med 78:785-794

3. Ballard DJ, Humphrey LL, Melton LJ 3rd et al (1988) Epidemiology of persistent proteinuria in Type II diabetes mellitus. Population-based study in Rochester, Minnesota. Diabetes 37:405-412

4. Rossing P (2005) The changing epidemiology of diabetic microangiopathy in type 1 diabetes. Diabetologia 48:1439-1444

5. Mogensen CE, Keane WF, Bennett PH et al (1995) Prevention of diabetic renal disease with special reference to microalbuminuria. Lancet 346:1080-1084

6. Rossing P, Hougaard P, Parving HH (2002) Risk factors for development of incipient and overt diabetic nephropathy in type 1 diabetic patients: a 10-year prospective observational study. Diabetes Care 25: 859-864

7. Hovind P, Tarnow L, Rossing P et al (2004) Predictors for the development of microalbuminuria and macroalbuminuria in patients with type 1 diabetes: inception cohort study. Br Med J 328:1105

8. Seaquist ER, Goetz FC, Rich S, Barbosa J (1989) Familial clustering of diabetic kidney disease: Evidence of genetic susceptibility to diabetic nephropathy. N Engl J Med 320: 1161-1165

9. Pettitt DJ, Saad MF, Bennett PH, Nelson RG, Knowler WC (1990) Familial predisposition to renal disease in two generations of Pima Indians with Type 2 (non-insulin-dependent) diabetes mellitus. Diabetologia 33:438-443

10. Borch-Johnsen K, Nørgaard K, Hommel E et al (1992) Is diabetic nephropathy an inherited complication? Kidney Int 41:719-722

11. Cowie CC, Port FK, Wolfe RA, Savage PJ, Moll PP, Hawthorne VM (1989) Disparities in incidence of diabetic end-stage renal disease according to race and type of diabetes. N Engl J Med 321:1074-1079

12. Tarnow L (2002) Diabetic nephropathy. Pathogenetic aspects and cardiovascular risk factors. Dan Med Bull 49:19-42

13. Tarnow L, Gluud C, Parving HH (1998) Diabetic nephropathy and the insertion/deletion polymorphism of the angiotensinconverting enzyme gene. Nephrol Dial Transplant 13:1125-1130

14. Brenner BM, Chertow GM (1994) Congenital oligonephropathy and the etiology of adult hypertension and progressive renal injury. Am J Kidney Diseases 23:171-175

15. Rossing P, Tarnow L, Nielsen FS, Boelskifte S, Brenner BM, Parving HH (1995) Short stature and diabetic nephropathy. Br Med J 310:296-297

16. Gould MM, Mohamed-Ali V, Goubet SA, Yudkin JS, Haines AP (1993) Microalbuminuria: associations with height and sex in non-diabetic subjects. Br Med J 306:240-242

17. Rossing P, Tarnow L, Nielsen FS, Hansen BV, Brenner BM, Parving HH (1995) Low birth weight. A risk factor for development of diabetic nephropathy? Diabetes 44: 1405-1407
18. Luyckx VA, Brenner BM (2005) Low birth weight, nephron number, and kidney disease. Kidney Int Suppl S68-S77

19. Mathiesen ER, Rønn B, Jensen T, Storm B, Deckert T (1990) Relationship between blood pressure and urinary albumin excretion in development of microalbuminuria. Diabetes 39:245-249

20. Coonrod BA, Ellis D, Becker DJ et al (1993) Predictors of microalbuminuria in individuals with IDDM. Pittsburgh Epidemiology of Diabetes Complications Study. Diabetes Care $16: 1376-1383$

21. Microalbuminuria Collaborative Study Group UK (1999) Predictors of the development of microalbuminuria in patients with type 1 diabetes mellitus: a seven year prospective study. Diabetic Med 16:918-925

22. Chaturvedi N, Bandinelli S, Mangili R et al (2001) Microalbuminuria in type 1 diabetes: rates, risk factors and glycemic threshold. Kidney Int 60:219-227

23. Lurbe E, Redon J, Kesani A et al (2002) Increase in nocturnal blood pressure and progression to microalbuminuria in type 1 diabetes. N Engl J Med 347:797-805

24. Daneman D, Crompton CH, Balfe JA et al (1994) Plasma prorenin as an early marker of nephropathy in diabetic (IDDM) adolescents. Kidney Int 46:1154-1159

25. Deinum J, Rønn B, Mathiesen ER, Derkx FHM, Hop WCJ, Schalekamp MADH (1999) Increase in serum prorenin precedes onset of microalbuminuria in patients with insulindependent diabetes mellitus. Diabetologia 42:1006-1010

26. Ahmed SB, Hovind P, Parving $\mathrm{HH}$ et al (2005) Oral contraceptives, angiotensin-dependent renal vasoconstriction, and risk of diabetic nephropathy. Diabetes Care 28:1988-1994

27. Monster TB, Janssen WM, de Jong PE, de Jong-van den Berg LT (2001) Oral contraceptive use and hormone replacement therapy are associated with microalbuminuria. Arch Intern Med 161:2000-2005

28. Pirart J (1978) Diabetes mellitus and its degenerative complications: a prospective study of 4,400 patients observed between 1947 and 1973. Diabetes Care 1:168-188

29. Rossing P, Hougaard P, Parving HH (2002) Risk factors for development of incipient and overt diabetic nephropathy in Type 1 diabetic patients. Diabetes Care 25:859-864

30. Scott LJ, Warram JH, Hanna LS, Laffel LM, Ryan L, Krolewski AS (2001) A nonlinear effect of hyperglycemia and current cigarette smoking are major determinants of the onset of microalbuminuria in type 1 diabetes. Diabetes 50:2842-2849

31. Wang PH, Lau J, Chalmers TC (1993) Meta-analysis of effects of intensive blood-glucose control on late complications of type I diabetes. Lancet 341:1306-1309

32. The Diabetes Control and Complications Trial Research Group. (1993) The effect of intensive treatment of diabetes on the development and progression of long-term complications in insulin-dependent diabetes mellitus. N Engl J Med 329:977-986

33. Brownlee M (2001) Biochemistry and molecular cell biology of diabetic complications. Nature 414:813-820

34. Du XL, Edelstein D, Rossetti L et al (2000) Hyperglycemiainduced mitochondrial superoxide overproduction activates the hexosamine pathway and induces plasminogen activator inhibitor-1 expression by increasing Sp1 glycosylation. Proc Natl Acad Sci USA 97:12222-12226

35. Nishikawa T, Edelstein D, Du XL et al (2000) Normalizing mitochondrial superoxide production blocks three pathways of hyperglycaemic damage. Nature 404:787-790

36. Chase HP, Garg SK, Marshall G et al (1991) Cigarette smoking increases the risk of albuminuria among subjects with type 1 diabetes. JAMA 265:614-617

37. Mathiesen ER, Rønn B, Foght H, Deckert T (1995) The natural course of microalbuminuria in insulin-dependent diabetes: a 10year prospective study. Diabetic Med 12:482-487

38. Hansen HP, Rossing P, Jacobsen P, Jensen BR, Parving HH (1996) The acute effect of smoking on systemic haemodynamics, kidney and endothelial function in insulin-dependent diabetic patients with microalbuminuria. Scand J Clin Lab Invest 56:393-399 
39. Sawicki PT, Didjurgeit U, Mühlhauser I, Bender R, Heinemann L, Berger M (1994) Smoking is associated with progression of diabetic nephropathy. Diabetes Care 17:126-131

40. Hovind P, Rossing P, Tarnow L, Parving HH (2003) Smoking and progression of diabetic nephropathy in type 1 diabetes. Diabetes Care 26:911-916

41. Parving HH, Oxenbøll B, Svendsen PA, Christiansen JS, Andersen AR (1982) Early detection of patients at risk of developing diabetic nephropathy. Acta Endocrinol (Copenh) 100:550-555

42. Viberti GC, Hill RD, Jarrett RJ, Argyropoulos A, Mahmud U, Keen H (1982) Microalbuminuria as a predictor of clinical nephropathy in insulin-dependent diabetes mellitus. Lancet i: $1430-1432$

43. Mogensen CE, Christensen CK (1984) Predicting diabetic nephropathy in insulin-dependent patients. N Engl J Med 311:89-93

44. Rossing P, Hougaard P, Parving HH (2005) Progression of microalbuminuria in type 1 diabetes: ten-year prospective observational study. Kidney Int 68:1446-1450

45. Chaturvedi N (2001) Should all patients with type 1 diabetes mellitus and microalbuminuria receive angiotensin-converting enzyme inhibitors? A meta-analysis of individual patient data. Ann Intern Med 134:370-379

46. Perkins BA, Ficociello LH, Silva KH, Finkelstein DM, Warram JH, Krolewski AS (2003) Regression of microalbuminuria in type 1 diabetes. N Engl J Med 348:2285-2293

47. Caramori ML, Fioretto P, Mauer M (2000) The need for early predictors of diabetic nephropathy risk: is albumin excretion rate sufficient? Diabetes 49:1399-1408

48. Forsblom CM, Groop P-H, Ekstrand A, Groop L (1992) Predictive value of microalbuminuria in patients with insulindependent diabetes of long duration. Br Med J 305:1051-1053

49. Arun CS, Stoddart J, Mackin P, MacLeod JM, New JP, Marshall SM (2003) Significance of microalbuminuria in longduration type 1 diabetes. Diabetes Care 26:2144-2149

50. Giorgino F, Laviola L, Cavallo PP, Solnica B, Fuller J, Chaturvedi N (2004) Factors associated with progression to macroalbuminuria in microalbuminuric Type 1 diabetic patients: the EURODIAB Prospective Complications Study. Diabetologia 47:1020-1028

51. Warram JH, Scott LJ, Hanna LS et al (2000) Progression of microalbuminuria to proteinuria in type 1 diabetes: nonlinear relationship with hyperglycemia. Diabetes 49:94-100

52. Microalbuminuria Collaborative Study Group, UK (1995) Intensive therapy and progression to clinical albuminuria in patients with insulin dependent diabetes mellitus and microalbuminuria. BMJ 311:973-977

53. Hansen KW, Christensen CK, Andersen PH, Mau Pedersen M, Christiansen JS, Mogensen CE (1992) Ambulatory blood pressure in microalbuminuric type 1 diabetic patients. Kidney Int 41:847-854

54. Thomas W, Shen Y, Molitch ME, Steffes MW (2001) Rise in albuminuria and blood pressure in patients who progressed to diabetic nephropathy in the Diabetes Control and Complications Trial. J Am Soc Nephrol 12:333-340

55. Parving HH, Lehnert H, Bröchner-Mortensen J, Gomis R, Andersen S, Arner P (2001) The effect of Irbesartan on the development of diabetic nephropathy in patients with type 2 diabetes. N Engl J Med 345:870-878

56. Mathiesen ER, Hommel E, Hansen HP, Smidt UM, Parving HH (1999) Randomised controlled trial of long term efficacy of captopril on preservation of kidney function in normotensive patients with insulin dependent diabetes and microalbuminuria. Br Med J 319:24-25

57. Hansen HP, Lund SS, Rossing P et al (2001) Preventing diabetic nephropathy: an audit. Scand J Clin Lab Invest 61:471-477

58. Almdal T, Nørgaard K, Feldt-Rasmussen B, Deckert T (1994) The predictive value of microalbuminuria in IDDM. Diabetes Care 17:120-125
59. The Diabetes Control and Complications Trial Research Group (1995) Effect of intensive therapy on the development and progression of diabetic nephropathy in the diabetes control and complications trial. Kidney Int 47:1703-1720

60. Fioretto P, Steffes MW, Sutherland DER, Goetz FC, Mauer SM (1998) Reversal of lesions of diabetic nephropathy after pancreas transplantation. N Engl J Med 339:69-75

61. Yip J, Mattock MB, Morocutti A, Sethi M, Trevisan R, Viberti GC (1993) Insulin resistance in insulin-dependent diabetic patients with microalbuminuria. Lancet 342:883-887

62. Orchard TJ, Chang YF, Ferrell RE, Petro N, Ellis DE (2002) Nephropathy in type 1 diabetes: a manifestation of insulin resistance and multiple genetic susceptibilities? Further evidence from the Pittsburgh Epidemiology of Diabetes Complication Study. Kidney Int 62:963-970

63. Earle K, Walker J, Hill C, Viberti GC (1992) Familial clustering of cardiovascular disease in patients with insulin-dependent diabetes and nephropathy. N Engl J Med 326:673-677

64. Tarnow L, Rossing P, Nielsen FS, Fagerudd JA, Poirier O, Parving HH (2000) Cardiovascular morbidity and early mortality cluster in parents of type 1 diabetic patients with diabetic nephropathy. Diabetes Care 23:30-33

65. Stuveling EM, Bakker SJ, Hillege HL, de Jong PE, Gans RO, de ZD (2005) Biochemical risk markers: a novel area for better prediction of renal risk? Nephrol Dial Transplant 20:497-508

66. Schalkwijk CG, Poland DC, van DW et al (1999) Plasma concentration of C-reactive protein is increased in type I diabetic patients without clinical macroangiopathy and correlates with markers of endothelial dysfunction: evidence for chronic inflammation. Diabetologia 42:351-357

67. Schram MT, Chaturvedi N, Schalkwijk CG, Fuller JH, Stehouwer CD (2005) Markers of inflammation are crosssectionally associated with microvascular complications and cardiovascular disease in type 1 diabetes-the EURODIAB Prospective Complications Study. Diabetologia 48:370-378

68. Stehouwer CDA, Stroes ESG, Hackeng WHL, Mulder PGH, den Ottolander GJH (1991) von Willebrand factor and development of diabetic nephropathy in IDDM. Diabetes 40:971-976

69. Hovind P, Hansen TK, Tarnow L et al (2005) Mannose-binding lectin as a predictor of microalbuminuria in type 1 diabetes: an inception cohort study. Diabetes 54:1523-1527

70. Hovind P, Tarnow L, Oestergaard PB, Parving HH (2000) Elevated vascular endothelial growth factor in type 1 diabetic patients with diabetic nephropathy. Kidney Int Suppl 75:S56-S61

71. Steinke JM, Sinaiko AR, Kramer MS, Suissa S, Chavers BM, Mauer M (2005) The early natural history of nephropathy in Type 1 Diabetes: III. Predictors of 5-year urinary albumin excretion rate patterns in initially normoalbuminuric patients. Diabetes 54:2164-2171

72. Eikmans M, Baelde HJ, Hagen EC, et al (2003) Renal mRNA levels as prognostic tools in kidney diseases. J Am Soc Nephrol 14:899-907

73. Mogensen CE (1976) Progression of nephropathy in long-term diabetics with proteinuria and effect of initial antihypertensive treatment. Scand J Clin Lab Invest 36:383-388

74. Parving HH, Smidt UM, Friisberg B, Bonnevie-Nielsen V, Andersen AR (1981) A prospective study of glomerular filtration rate and arterial blood pressure in insulin-dependent diabetics with diabetic nephropathy. Diabetologia 20:457-461

75. Viberti GC, Bilous RW, Mackintosh D, Keen H (1983) Monitoring glomerular function in diabetic nephropathy. Am J Med 74:256-264

76. Rossing P, Hommel E, Smidt UM, Parving HH (1993) Impact of arterial blood pressure and albuminuria on the progression of diabetic nephropathy in IDDM patients. Diabetes 42:715-719

77. Björck S, Mulec H, Johnsen SA, Nordén G, Aurell M (1992) Renal protective effect of enalapril in diabetic nephropathy. $\mathrm{Br}$ Med J 304:339-343

78. Lewis E, Hunsicker L, Bain R, Rhode R (1993) The effect of angiotensin-converting-enzyme inhibition on diabetic nephropathy. N Engl J Med 329:1456-1462 
79. Elving LD, Wetzels JFM, van Lier HJJ, de Nobel E, Berden JHM (1994) Captopril and atenolol are equally effective in retarding progression of diabetic nephropathy. Diabetologia 37:604-609

80. Tarnow L, Rossing P, Jensen C, Hansen BV, Parving HH (2000) Long-term renoprotective effect of nisoldipine and lisinopril in type 1 diabetic patients with diabetic nephropathy. Diabetes Care 23:1725-1730

81. Parving HH (1998) Renoprotection in diabetes: genetic and nongenetic risk factors and treatment. Diabetologia 41:745-759

82. Rossing P (1998) Promotion, prediction, and prevention of progression in diabetic nephropathy. Diabetic Med 15:900-919

83. Jacobsen PK (2005) Preventing end stage renal disease in diabetic patients - genetic aspect (part I). J Renin Angiotensin Aldosterone Syst 6:1-14

84. Jacobsen P, Tarnow L, Carstensen B, Hovind P, Poirier O, Parving HH (2003) Genetic variation in the renin-angiotensin system and progression of diabetic nephropathy. J Am Soc Nephrol 14:2843-2850

85. Parving HH, Jacobsen P, Tarnow L et al (1996) Deleterious effect of a deletion polymorphism in angiotensin-converting enzyme (ACE) gene on progression of diabetic nephropathy during ACE inhibition. Br Med J 313:591-594

86. Andersen S, Tarnow L, Cambien F et al (2003) Long-term renoprotective effects of losartan in diabetic nephropathy: interaction with ACE insertion/deletion genotype? Diabetes Care 26:1501-1506

87. Kurland L, Melhus H, Karlsson J et al (2001) Angiotensin converting enzyme gene polymorphism predicts blood pressure response to angiotensin II receptor type 1 antagonist treatment in hypertensive patients. J Hypertens 19:1783-1787

88. Hovind P, Rossing P, Tarnow L, Smidt UM, Parving HH (2001) Progression of diabetic nephropathy. Kidney Int 59:702-709

89. Rossing P, Hommel E, Smidt UM, Parving HH (1994) Reduction in albuminuria predicts a beneficial effect on diminishing the progression of human diabetic nephropathy during antihypertensive treatment. Diabetologia 37:511-516

90. Breyer JA, Bain R, Evans JK et al (1996) Predictors of the progression of renal insufficiency in patients with insulindependent diabetes and overt diabetic nephropathy. Kidney Int 50:1651-1658

91. Rossing K, Mischak H, Parving HH et al (2005) Impact of diabetic nephropathy and angiotensin II receptor blockade on urinary polypeptide patterns. Kidney Int 68:193-205

92. Andersen S, Rossing P, Juhl TR, Deinum J, Parving HH (2002) Optimal dose of losartan for renoprotection in diabetic nephropathy. Nephrol Dial Transplant 17:1413-1418

93. Rossing K, Christensen PK, Hansen BV, Carstensen B, Parving HH (2003) Optimal dose of Candesartan for renoprotection in type 2 diabetic patients with nephropathy: a double-blind randomized crossover study. Diabetes Care 26:150-155

94. Rossing K, Schjoedt KJ, Jensen BR, Boomsma F, Parving HH (2005) Enhanced renoprotective effects of ultrahigh doses of irbesartan in patients with type 2 diabetes and microalbuminuria. Kidney Int 68:1190-1198

95. Hollenberg NK, Fisher NDL, Price DA (1998) Pathways for angiotensin II generation in intact human tissue. Evidence from comparative pharmacological interruption of the renin system. Hypertension 32:387-392

96. Cao Z, Bonnet F, Candido R et al (2002) Angiotensin type 2 receptor antagonism confers renal protection in a rat model of progressive renal injury. J Am Soc Nephrol 13:1773-1787

97. Mogensen CE, Neldam S, Tikkanen I et al (2000) Randomised controlled trial of dual blockade of renin-angiotensin system in patients with hypertension, microalbuminuria, and non-insulin dependent diabetes: the candesartan and lisinopril microalbuminuria (CALM) study. BMJ 321:1440-1444
98. Jacobsen P, Andersen S, Rossing K, Hansen BV, Parving HH (2002) Dual blockade of the renin-angiotensin system in type 1 patients with diabetic nephropathy. Nephrol Dial Transplant 17:1019-1024

99. Rossing K, Christensen PK, Jensen BR, Parving HH (2002) Dual blockade of the renin-angiotensin system in diabetic nephropathy: a randomized double-blind crossover study. Diabetes Care 25:95-100

100. Andersen NH, Poulsen PL, Knudsen ST et al (2005) Long-term dual blockade with candesartan and lisinopril in hypertensive patients with diabetes: the CALM II study. Diabetes Care 28:273-277

101. Jacobsen P, Andersen S, Rossing K, Jensen BR, Parving HH (2003) Dual blockade of the renin-angiotensin system versus maximal recommended dose of ACE inhibition in diabetic nephropathy. Kidney Int 63:1874-1880

102. Nakao N, Yoshimura A, Morita H et al (2003) Combination therapy of angiotensin-II receptor blocker and angiotensinconverting enzyme inhibitor in non-diabetic renal disease: a randomized, controlled trial in Japan (COOPERATE). Lancet 361:117-124

103. Epstein M (2001) Aldosterone and the hypertensive kidney: its emerging role as a mediator of progressive renal dysfunction: a paradigm shift. J Hypertens 19:829-842

104. Sato A, Hayashi K, Naruse M, Saruta T (2003) Effectiveness of aldosterone blockade in patients with diabetic nephropathy. Hypertension 41:64-68

105. Schjoedt KJ, Andersen S, Rossing P, Tarnow L, Parving HH (2004) Aldosterone escape during blockade of the reninangiotensin-aldosterone system in diabetic nephropathy is associated with enhanced decline in glomerular filtration rate. Diabetologia 47:1936-1939

106. Rossing K, Schjoedt KJ, Smidt UM, Boomsma F, Parving HH (2005) Beneficial effects of adding spironolactone to recommended antihypertensive treatment in diabetic nephropathy: a randomized, double-masked, cross-over study. Diabetes Care 28:2106-2112

107. Schjoedt KJ, Rossing K, Juul T, Boomsma F, Tarnow L, Parving HH (2005) Beneficial impact of spironolactone in diabetic nephropathy. Diabetologia 48:A6 (Abstract)

108. Rossing P, Hougaard P, Borch-Johnsen K, Parving HH (1996) Predictors of mortality in insulin dependent diabetes: 10 year follow-up study. BMJ 313:779-784

109. Mogensen CE (1984) Microalbuminuria predicts clinical proteinuria and early mortality in maturity onset diabetes. N Engl J Med 310:356-360

110. MacLeod JM, Lutale J, Marshall SM (1995) Albumin excretion and vascular deaths in NIDDM. Diabetologia 38:610-616

111. Gall M-A, Borch-Johnsen K, Hougaard P, Nielsen FS, Parving HH (1995) Albuminuria and poor glycemic control predict mortality in NIDDM. Diabetes 44:1303-1309

112. Knowles HCJ (1971) Long-term juvenile diabetes treated with unmeasured diet. Trans Assoc Am Physicians 84:95-101

113. Parving HH, Jacobsen P, Rossing K, Smidt UM, Hommel E, Rossing P (1996) Benefits of long-term antihypertensive treatment on prognosis in diabetic nephropathy. Kidney Int 49:1778-1782

114. Astrup AS, Tarnow L, Rossing P, Pietraszek L, Riis HP, Parving HH (2005) Improved prognosis in type 1 diabetic patients with nephropathy: a prospective follow-up study. Kidney Int 68:1250-1257

115. Brenner BM, Garcia DL, Anderson S (1988) Glomeruli and blood pressure. Less of one, more the other? Am J Hypertens $1: 335-347$ 